\title{
Effect of concentrate supplementation during pre-kidding on the productive and reproductive performance of goats raised on Guinea grass (Panicum maximum cv. Tobiatã) pasture
}

\section{Suplementação de concentrado na fase pré-parto no desempenho produtivo e reprodutivo de cabras mantidas em pastagem de capim- tobiatã (Panicum maximum cv. Tobiatã)}

\author{
Raquel Ornelas Marques ${ }^{1 *}$; Heraldo Cesar Gonçalves²; \\ Paulo Roberto de Lima Meirelles²; Gil Ignácio Lara Cañizares ${ }^{1}$; \\ Giuliana Micai de Oliveira3; Helen Fernanda Barros Gomes ${ }^{4}$; Simone Fernandes ${ }^{2}$; \\ Aline Aparecida de Oliveira ${ }^{1}$; Évelyn Prestes Brito ${ }^{1}$; Raphaela Felipe Carmo $^{3}$
}

\begin{abstract}
Sixty goats (20 Alpine, 18 Anglo-Nubian, and 22 crossbred Boer), with average body weight $49.33 \pm$ $1.41 \mathrm{~kg}$, were raised on Panicum maximum cv. Tobiatã pasture with two different levels of concentrate supplementation, 300 (SL30) and $600 \mathrm{~g} \mathrm{~kg}^{-1}$ (SL60) of the daily requirements, and evaluated from the pre-mating season until an average of 110 days of lactation. Milk controls were performed every 14 days. The following milk production curve parameters were estimated: time to reach peak milk production (TP), peak milk production (PP) and milk production during the first 110 days of lactation (MP). The following milk components were determined: fat, protein, lactose, total solids (TS), defatted dry extract (DDE), urea nitrogen (UN) concentrations, and somatic cell count (SCC). Goat prolificacy and birth weight of the kids were also determined. Breed affected the lactation curve, with Alpine and AngloNubian goats presenting higher TP, PP, and MP. Protein, TS, and DDE concentrations were also affected by breed, being higher for crossbred Boer goats. Milk fat, lactose concentrations, and the log of SCC were affected by the concentrate supplementation level, being higher for SL30, as well as by the breed, with crossbred Boer goats presenting higher fat concentrations and $\log$ of SCC, and crossbred Boer and Alpine goats presenting higher lactose concentrations. UN was affected by the stage of lactation. Prolificacy and birth weight were affected by breed and concentrate supplementation level, being higher for Anglo-Nubian and crossbred Boer goats with SL60. Kids from single births presented higher birth weights. The Anglo-Nubian breed presented good milk production and the best body condition, which might indicate the effectiveness of this production system, SL60 supplementation resulted in higher birth weight and prolificacy.
\end{abstract}

Key words: Goats. Milk composition. Birth weight. Milk production. Prolificacy.

\footnotetext{
${ }^{1}$ Discentes do Programa de Pós-Graduação em Zootecnia, Faculdade de Medicina Veterinária e Zootecnia, FMVZ, Universidade Estadual Paulista "Julio de Mesquita Filho", UNESP, Botucatu, SP, Brasil. E-mail: ra_ornelas@yahoo.com.br; inabra68@, hotmail.com; aline_btu@ig.com.br; evelynprestes_zoo@hotmail.com

${ }^{2}$ Profs., Programa de Pós-Graduação em Zootecnia, FMVZ/UNESP, Botucatu, SP, Brasil. E-mail: heraldo@fmvz.unesp.br; paulom@fmvz.unesp.br; simone.fernandes@fmvz.unesp.br

3 Discentes de Graduação em Zootecnia, FMVZ/UNESP, Botucatu, SP, Brasil. E-mail: giuliana.micai@hotmail.com; rapha.4@ hotmail.com

${ }^{4}$ Prof $^{\mathrm{a}}$, Universidade Federal de Mato Grosso, UFMT, Sinop, MT, Brasil. E-mail: gomesh@ufmt.br

* Author for correspondence
} 


\title{
Resumo
}

\begin{abstract}
Foram utilizadas 60 cabras (20 Alpina, 18 Anglo-Nubiana e 22 mestiças Boer), com peso corporal médio de 49,33 $\pm 1,41 \mathrm{~kg}$, mantidas em pastagem com Panicum maximum cv. Tobiatã e suplementadas com dois níveis de concentrado: 300 (NS30) e $600 \mathrm{~g} \mathrm{~kg}^{-1}$ (NS60) das exigências diárias, avaliadas desde a pré-estação de monta, até, em média 110 dias de lactação. O controle leiteiro foi realizado a cada 14 dias, estimando-se as características da curva de produção: tempo para atingir o pico (TP), produção no pico (PP) e produção de leite até 110 dias de lactação (PL); os constituintes: gordura, proteína, lactose, sólidos totais (ST), extrato seco desengordurado (ESD), nitrogênio ureico (NU) e contagem de células somáticas (CCS); além da prolificidade das cabras e o peso ao nascer dos cabritos. O grupo racial influenciou a curva de lactação, sendo que as Alpinas e Anglo-Nubianas apresentaram maior TP, PP e PL. Os teores de proteína, ST e ESD foram influenciados pelo grupo racial, tendo as mestiças Boer apresentado maiores teores. Os teores de gordura, lactose e o $\log$ da CCS foram influenciados pelo tratamento, sendo o NS30 com maiores valores, e pelo grupo racial, tendo as mestiças Boer apresentado maiores valores para teores de gordura e $\log$ da CCS, e as mestiças Boer e as Alpinas maiores valores para a lactose. O NU foi influenciado pelo estádio da lactação. A prolificidade e o peso ao nascer foram influenciados pelo grupo racial e tratamento, sendo que as Anglo-Nubianas e mestiças Boer do NS60 apresentaram melhores resultados. Os cabritos de partos simples tiveram maiores pesos ao nascer. A raça Anglo-Nubiana pode ser indicada para esse sistema de produção, pela boa produção de leite e melhor condição corporal. A suplementação NS60 favoreceu o peso ao nascer e a prolificidade.
\end{abstract}

Palavras-chave: Caprinos. Composição de leite. Peso ao nascer. Produção de leite. Prolificidade.

\section{Introduction}

Over the last decade, there has been an increase in the number of goat milk processing plants in Southeast and South Brazil, leading to a demand for higher efficiency in milk production, through increased production and/or decreased production costs.

Traditionally, milk goats are raised in confinement, requiring large facilities and receiving all feed via the trough. However, this system has high production costs. The use of pasture-based production systems is one of the alternatives to decrease production costs. However, the efficiency of pasture-based milk production systems depends on several factors, such as the type of pasture, availability, and nutritional value of forage, use of supplements, and aptitude for milk production.

In the case of seasonal decreases in the quantity and quality of forage, or if the animals present higher milk production potential than can be sustained by the pasture, supplementation with good quality concentrates and/or roughage is essential for the animals to reach their full production potential.
Ingestion of dry mass and energy during lactation are positively correlated with milk production. Any improvement in the nutritional management, especially in the quality of forage and feed, results in increased milk production. Concentrate supplementation of diets of lactating goats is the principal method of manipulation of milk production and composition (RODRIGUES et al., 2007).

Adequate energy supplementation during pregnancy enables storage of energy reserves, resulting in better body condition at birth, minimizing the negative effects of fat mobilization during early lactation, and an increase in milk production and weight gain (EKNAES et al., 2006).

Understanding the relationship of body condition with diet energy levels, ingestion, weight gain, milk production, and mobilization of body reserves, at each physiological stage of the animal, is fundamental for recommending management measures with the aim of maximizing herd production efficiency (RODRIGUES et al., 2006a). 
Fertility and prolificacy are the most important reproductive characteristics for goat-milk production systems (MEDEIROS et al., 2006). Good reproductive indices result in high number of kids born per year, enabling higher selection intensity, and consequently improving production, regardless of the breeding purpose. Nutritional level of the dietary matrix at conception, along with the season and year, as well as goat breed, age and weight, can affect prolificacy rates and animal fertility (SARMENTO et al., 2010).

Considering the lack of information about pasture-based dairy goat breeding, the aim of the present study was to evaluate the effect of concentrate supplementation from the premating season until kidding on reproductive and productive performance and milk composition of goats from two pure breeds (Alpine and AngloNubian) and crossbred Boer, raised on pastures of Guinea grass Tobiatã with a rotational grazing system.

\section{Material and Methods}

The present study was conducted at the Faculty of Veterinary Medicine and Zootechnics of the State University of São Paulo (UNESP), Botucatu Campus, São Paulo (SP), in the Goat Production Area, located within the Lageado Farm. The study was approved by the animal experimentation ethics committee of the UNESP (protocol no. 20/2010 CEUA). The experimental area is located at latitude $22^{\circ} 52^{\prime} \mathrm{S}$ and longitude $48^{\circ} 26^{\prime} \mathrm{W}$, at an altitude of $800 \mathrm{~m}$. The region's climate is Cwa, hot temperate mesothermal, according to the Köppen climate classification. The average annual rainfall is 1479 mm (ROLIM et al., 2007), and the dry season lasts from May through September $30 \%$ of the total annual rainfall).

A total of 60 goats were used, of which 20 were Alpine, 18 Anglo-Nubian, and 22 crossbred Boer (11 1/2 Boer + 1/2 Alpine and 11 3/4 Boer + 1/4 Alpine). The goats were primiparous or multiparous, with average body weight of $49.33 \pm 1.41 \mathrm{~kg}$. The goats were released into Panicum maximum cv. Tobiatã pastures from $0800 \mathrm{~h}$ to $1800 \mathrm{~h}$ on the grazing days of the experiment. A rotational grazing system was used, with variable stocking rate. Two levels of concentrate supplementation were tested, determined according to the breed and level of concentrate supplementation during pre-kidding (Table 1). Forage availability was controlled by adjusting the stocking rates at each paddock every three days, using grazer animals of the same breed and employing the put-and-take stocking method. A total area of approximately 0.6 ha was used, divided into 10 paddocks of approximately $500 \mathrm{~m}^{2}$ each. The period of occupation of each paddock was three days, and the rest period was 27 days. All paddocks were equipped with an automatic drinking trough and a freely accessible rest area with artificial shade provided by shade net $(75 \%$ solar radiation retention), located on the access corridor to the paddocks.

Table 1. Distribution of goats according to breed and pre-kidding concentrate supplementation level.

\begin{tabular}{|c|c|c|c|c|c|}
\hline \multirow{3}{*}{ Breed } & \multicolumn{4}{|c|}{ Concentrate Supplementation Level ${ }^{1}$} & \multirow{3}{*}{ Total } \\
\hline & \multicolumn{2}{|c|}{ SL30 } & \multicolumn{2}{|c|}{ SL60 } & \\
\hline & Primiparous & Multiparous & Primiparous & Multiparous & \\
\hline Alpine & 5 & 5 & 5 & 5 & 20 \\
\hline Anglo-Nubian & 5 & 4 & 5 & 4 & 18 \\
\hline Boer Crossbred & 6 & 5 & 6 & 5 & 22 \\
\hline Total & 16 & 14 & 16 & 14 & 60 \\
\hline
\end{tabular}

${ }^{1}$ SL30: $300 \mathrm{~g} \mathrm{~kg}^{-1}$ of the daily nutritional requirements, and SL60: $600 \mathrm{~g} \mathrm{~kg}^{-1}$ of the daily nutritional requirements. 
The goat mating season began at the end of summer and lasted 90 days, until the end of autumn. Kidding occurred from mid-winter until spring.

Two levels of concentrate supplementation were tested: $300 \mathrm{~g} \mathrm{~kg}^{-1}$ (SL30) and $600 \mathrm{~g} \mathrm{~kg}^{-1}$ (SL60) of the daily nutrient requirements (NRC, 2006), based on an intake of $22 \mathrm{~g} \mathrm{~kg}^{-1}$ live weight of the dry matter. Concentrate was supplied from one month before the mating season until kidding, when lactation was evaluated.

Following kidding, concentrate supply was adjusted such that that $1 \mathrm{~kg}$ concentrate would sustain the production of $2.5 \mathrm{~kg}$ milk. The amount of concentrate supplied was corrected every fourteen days. The pre-kidding concentrate consisted of $450 \mathrm{~g} \mathrm{~kg}^{-1}$ corn, $100 \mathrm{~g} \mathrm{~kg}^{-1}$ soybean meal, $410 \mathrm{~g} \mathrm{~kg}^{-1}$ cotton meal, $25 \mathrm{~g} \mathrm{~kg}^{-1}$ limestone, $5 \mathrm{~g} \mathrm{~kg}^{-1}$ dicalcium phosphate, and $10 \mathrm{~g} \mathrm{~kg}^{-1}$ mineral supplement. The concentrate supplied during lactation consisted of $520 \mathrm{~g} \mathrm{~kg}^{-1}$ corn, $290 \mathrm{~g} \mathrm{~kg}^{-1}$ soybean meal, $150 \mathrm{~g} \mathrm{~kg}^{-1}$ wheat meal, $25 \mathrm{~g} \mathrm{~kg}^{-1}$ limestone, $5 \mathrm{~g} \mathrm{~kg}^{-1}$ dicalcium phosphate, and $10 \mathrm{~g} \mathrm{~kg}^{-1}$ mineral supplement. Bromatological composition of the concentrates used is presented in Table 2.

Table 2. Chemical composition of concentrate diets.

\begin{tabular}{|c|c|c|}
\hline Chemical composition (g/kg DM) & Pré-partum & Lactation \\
\hline Mineral matter & 78.5 & 71.3 \\
\hline Crude protein & 159.6 & 198.8 \\
\hline Ether extract & 36.6 & 38.6 \\
\hline Neutral detergent fiber & 198.7 & 184.3 \\
\hline Acid detergent fiber & 103.9 & 91.7 \\
\hline Non-fiber carbohydrates (NFC) ${ }^{1}$ & 526.6 & 507.0 \\
\hline Total digestible nutrients $(\mathrm{TDN})^{2}$ & 749.7 & 775.0 \\
\hline
\end{tabular}

${ }^{1}$ Achieved from the equation proposed by Van Soest et al. $(1991)$ : NFC $=100-(\mathrm{CP}+\mathrm{EE}+\mathrm{MM}+\mathrm{NDF})$.

${ }^{2}$ Achieved from the equation proposed by NRC (2006): TDN = DCP + DNFC + DNDF + (DFA x 2.25) - 7, where: DCP - truly digestible CP; DNFC - truly digestible CNF; DNDF - digestible NDF; DFA - truly digestible fatty acid.

Following grazing, the animals were herded into pens with slatted floors, suspended from the ground. They had access to a solarium with a concrete floor, and were kept segregated based on breed and supplementation level. At the pens, the animals received the concentrate, in addition to water and mineral salts.

Forage intake was calculated as the difference between forage available when the animals entered the paddocks and forage remaining when the animals exited the paddocks, using double sampling (SALMAN et al., 2006). A $1 \mathrm{~m} \times 1 \mathrm{~m}$ PVC quadrat was randomly thrown three times per paddock, and plant height was recorded at three points within the quadrat and all forage from $5 \mathrm{~cm}$ above the soil collected.

The forage bromatological composition was determined every season. Forage samples were dried at $55^{\circ} \mathrm{C}$ in a forced air ventilation oven until constant weight was achieved, processed using a Willey mill equipped with a $1-\mathrm{mm}$ sieve, and stored in plastic containers. The following parameters were quantified: mineral mater (MM), crude protein $(\mathrm{CP})$, ethereal extract (EE), neutral detergent fiber (NDF) and acid detergent fiber (ADF), and were corrected for dry matter (Table 3), according to the Association of Official Analytical Chemistry (AOAC, 2005) guidelines. 
During the experiment, fertilizations were performed every 30 days, with the application of 20 $\mathrm{kg}$ of 20-0-20 NPK per fertilization cycle, such that a total of $400 \mathrm{~kg}$ nitrogen and potassium was added per hectare year-1.

All animals received a dose of endectocide ( $1 \mathrm{ml}$ of $1 \%$ ivermectin per $50 \mathrm{~kg}$ body weight, applied subcutaneously) in the beginning of the experiment and following kidding. Feces samples were collected during the experiment directly from the rectal ampulla of each animal, and coprological tests were performed in order to control the number of eggs per gram of feces (EPG).

Table 3. Chemical composition of Tobiatã Grass in the pré and post-grazing.

\begin{tabular}{|c|c|c|c|c|}
\hline \multirow{2}{*}{ Chemical composition (g/kg DM) } & \multicolumn{4}{|c|}{ Pré- grazing } \\
\hline & Autumn & Winter & Spring & Summer \\
\hline Mineral matter & 53.0 & 45.8 & 54.1 & 50.8 \\
\hline Crude protein & 136.8 & 130.6 & 110.6 & 161.5 \\
\hline Ether extract & 20.7 & 22.0 & 19.0 & 26.8 \\
\hline Neutral detergent fiber & 643.2 & 669.3 & 710.7 & 627.8 \\
\hline Acid detergent fiber & 410.6 & 419.8 & 417.5 & 402.8 \\
\hline Non-fiber carbohydrates (NFC) ${ }^{1}$ & 146.4 & 132.3 & 105.7 & 133.2 \\
\hline \multirow[t]{2}{*}{ Total digestible nutrients $(\mathrm{TDN})^{2}$} & 625.5 & 605.0 & 602.0 & 630.4 \\
\hline & \multicolumn{4}{|c|}{ Post-grazing } \\
\hline Mineral matter & 84.0 & 76.8 & 89.1 & 81.8 \\
\hline Crude protein & 99.0 & 94.5 & 79.1 & 115.6 \\
\hline Ether extract & 27.7 & 26.8 & 17.0 & 30.1 \\
\hline Neutral detergent fiber & 783.2 & 794.4 & 784.6 & 768.6 \\
\hline Acid detergent fiber & 426.1 & 444.6 & 460.5 & 431.7 \\
\hline Non-fiber carbohydrates (NFC) ${ }^{1}$ & 6.1 & 7.5 & 30.3 & 3.9 \\
\hline Total digestible nutrients (TDN) ${ }^{2}$ & 566.0 & 563.8 & 540.3 & 570.2 \\
\hline
\end{tabular}

${ }^{1}$ Achieved from the equation proposed by Van Soest et al. (1991): NFC = $100-(\mathrm{CP}+\mathrm{EE}+\mathrm{MM}+\mathrm{NDF})$.

${ }^{2}$ Achieved from the equation proposed by NRC (2006).

The following parameters were analyzed: milk production after 110 days of lactation (MP), time to reach peak milk production (TP), peak milk production (PP), milk production on the control day (MPC), milk components, body weight, body condition score, prolificacy, and birth weight of the kids.

Twelve weight measurements were performed, using a manual scale with capacity up to $300 \mathrm{~kg}$ and $100-\mathrm{g}$ resolution, over the experimental period. Body condition scores were determined through palpation of the lumbar region every 30 days, until the end of the experiment.
Following birth, the kids were separated from their mothers and the umbilical cord was treated. Kids were weighed using a digital scale of $15 \mathrm{~kg}$ capacity and $5 \mathrm{~g}$ resolution, labelled, and given pasteurized colostrum.

Prolificacy was quantified using the following equation:

Prolificacy $=$ number of alive or dead kids (number of births) $)^{-1}$.

Milk control was performed every 14 days. Milk production on control day (MPC) was determined by performing two milkings, at $0600 \mathrm{~h}$ and $1800 \mathrm{~h}$, 
using a milking machine, and weighing the resulting milk using a digital scale of $15 \mathrm{~kg}$ capacity and $5 \mathrm{~g}$ resolution.

Milk components were determined in samples constituted from the morning ( $2 / 3$ parts) and afternoon (1/3 parts) milkings, proportional to the milk production. Samples were collected every 28 days, placed in $30 \mathrm{ml}$ plastic tubes containing bronopol (2-bromo-2-nitropropane-1,3-diol), and sent to the Milk Clinic of the Luiz de Queiroz College of Agriculture (ESALQ/USP, Piracicaba, SP). Milk fat, protein, lactose, total solids, defatted dry extract, urea nitrogen concentrations, and somatic cell counts, were determined, using a Bentley ${ }^{\circledR} 2000$ component analyzer.

Lactation curves were fitted using the individual milk control data $\left(\mathrm{kg}\right.$ milk day $\left.{ }^{-1}\right)$, according to the following model: $Y_{t}=a t^{b} \exp (-c t)$ (WOOD, 1980), where: $\mathrm{a}$ - initial milk production, $\mathrm{b}$ - rate of increase to peak production, $\mathrm{c}$ - persistence factor (indicating the rate of decline after peak production), and $t$ lactation day.

Using the parameter estimates from the model, the following indices were calculated: time to reach peak milk production (TP; days), peak milk production (PP; kg), and milk production during the first 110 days of lactation (MP; $\mathrm{kg}$ ), using the following equations: $T P=b / c ; P P=a(b / c)^{b} \exp ^{-b} \mathrm{e}$ $P L_{t}=a \int_{0}^{110} t^{b} \exp (-c t) d t$.

A completely randomized experimental design was used, with a $3 \times 2$ factorial scheme, the factors being three breeds (BR) and two concentrate supplementation levels (SL). Analysis of variance was performed for MP, TP, and PP (Model I).

Model I:

$Y_{i j k}=\mu+S L_{i}+B R_{j}+\left(S L^{*} B R\right)_{i j}+e_{i j k}$

where

$Y_{i j k}=$ parameter quantified for animal $\mathrm{k}$, from breed $\mathrm{j}$ and concentrate supplementation level $\mathrm{i}$; $\mu=$ constant associated to observations $Y_{i j k}$;

$S L_{i}=$ effect of the concentrate supplementation level i; $\mathrm{i}=1: 300 \mathrm{~g} \mathrm{~kg}^{-1}$ of the daily requirements, 2 : $600 \mathrm{~g} \mathrm{~kg}^{-1}$ of the daily requirements;

$B R_{j}=$ effect of breed $\mathrm{j} ; \mathrm{j}=1$ : Alpine, 2 : AngloNubian, 3: crossbred Boer;

$S L^{*} B R_{i j}=$ effect of the interaction between concentrate supplementation level $\mathrm{i}$ and breed $\mathrm{j}$;

$e_{i j k}=$ random error associated with observation $Y_{i j k} \sim \mathrm{N}\left(0, \sigma_{\mathrm{e}}^{2}\right)$.

Body weight, body condition score, MPC, and milk components were analyzed using a split-plot experimental design, considering BR, SL and their interaction as main plots, and MPC as sub-plot (Model II).

Model II:

$$
\begin{aligned}
& Y_{i j k l}=\mu+S L_{i}+B R_{j}+\left(S L^{*} B R\right)_{i j}+a_{k(i j)}+ \\
& C_{l}+I+e_{i j k l},
\end{aligned}
$$

where

$Y_{i j k}=$ parameter quantified for animal $\mathrm{k}$, from breed $\mathrm{j}$, concentrate supplementation level $\mathrm{i}$, during period 1;

$\mu=$ constant associated to observations $Y_{i j k l}$;

$S L_{i}=$ effect of the concentrate supplementation level $\mathrm{i} ; \mathrm{i}=1: 300 \mathrm{~g} \mathrm{~kg}^{-1}$ of the daily requirements, 2 : $600 \mathrm{~g} \mathrm{~kg}^{-1}$ of the daily requirements;

$B R_{j}=$ effect of breed $\mathrm{j} ; \mathrm{j}=1$ : Alpine, 2 : AngloNubian and 3: crossbred Boer;

$S L * B R_{i j}=$ effect of the interaction between concentrate supplementation level $\mathrm{i}$ and breed $\mathrm{j}$;

$\mathrm{a}_{\mathrm{k}(\mathrm{ij})}=$ effect of animal $\mathrm{k}$, within breed $\mathrm{j}$ and concentrate supplementation level i (error a);

$\mathrm{I}=$ interactions;

$\mathrm{e}_{\mathrm{ijkl}}=$ random error associated to observation $Y_{i j k l} \sim \mathrm{N}\left(0, \sigma_{\mathrm{e}}^{2}\right)$. 
Birth weight and prolificacy were analyzed using Model III.

Model III:

$Y_{i j k l m n}=\mu+S L_{i}+B R_{j}+S_{k}+T B_{l}+O B_{m}+$

$(I)_{i j k l m}+e_{i j k l m n}$

where

$Y_{i j k l m n}=$ parameter quantified for animal $\mathrm{n}$, concentrate supplementation level i, breed j, sex k, type of birth 1, and order of birth m;

$\mu=$ constant associated to observations $Y_{i j k l m n} ;$

$S L_{i}=$ effect of the supplementation level $\mathrm{i} ; \mathrm{i}=1$ : $300 \mathrm{~g} \mathrm{~kg}^{-1}$ of the daily requirements, $2: 600 \mathrm{~g} \mathrm{~kg}^{-1}$ of the daily requirements;

$B R_{j}=$ effect of breed $\mathrm{j} ; \mathrm{j}=1$ : Alpine, 2 : AngloNubian, 3: crossbred Boer;

$\mathrm{S}_{k}=$ effect of the kid's sex $\mathrm{k} ; \mathrm{k}=1$ : male, 2 : female;

$\mathrm{TP}_{l}=$ effect of the type of birth $1 ; 1=1$ : single, 2 : double, 3: triple;

$\mathrm{OP}_{m}=$ effect of birth order $\mathrm{m} ; \mathrm{m}=1$ : primipara, 2: multipara;

$I=$ effect of interactions between level of concentrate supplementation $\mathrm{i}$, breed $\mathrm{j}$, sex $\mathrm{k}$, type of birth 1, and birth order m;

$e_{i j k m n}=$ random error associated to observation $Y_{i j k l m n} \sim \mathrm{N}\left(0, \sigma_{\mathrm{e}}^{2}\right)$.

For all parameters except prolificacy, averages were compared using Tukey's test $(p<0.05)$. Prolificacy averages were compared using the $\chi^{2}$ test.

All statistical analyses were performed using the SAEG 9.0 software (UFV, 2000).

\section{Results and Discussion}

A significant interaction between breed and weighing was observed for body weight (Figure 1).
Anglo-Nubian goats presented lower weight than crossbred Boer, and not different from Alpine goats, for weighings 1 through 4 . This was probably due to higher number of primipara Anglo-Nubian goats, younger than one year old, and still in the growth phase. Similar results were reported for goats of the Canindé breed (MEDEIROS et al., 2004a). For weighings 5 through 12, no significant differences were observed between breeds.

Figure 1. Variation in live weight $(\mathrm{kg})$ over successive weighings for goats of different breeds and with different concentrate supplementation levels.

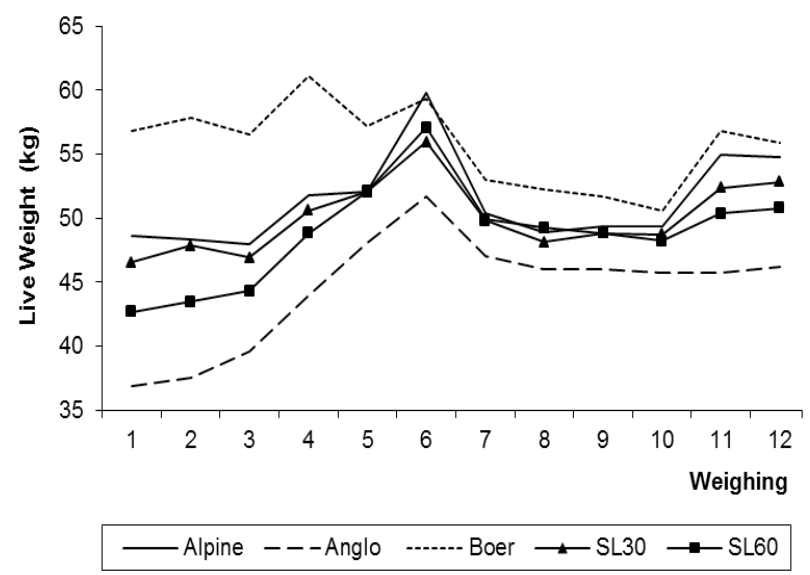

Average body weight decreased during the first 60 days, and increased again 120 days after kidding, for all breeds and concentrate supplementation levels, indicating that milk production during this period was sustained by mobilization of body energy reserves. No differences in live weight were observed between different supplementation levels.

A significant interaction between breed and level of concentrate supplementation was observed for the body condition score (Figure 2). During the first four evaluations, for both concentrate supplementation levels, body condition scores were higher for Anglo-Nubian than for Alpine goats, and not significantly different between Alpine and crossbred Boer goats. 
Figure 2. Variation in body condition score for goats of different breeds and with different concentrate supplementation levels.
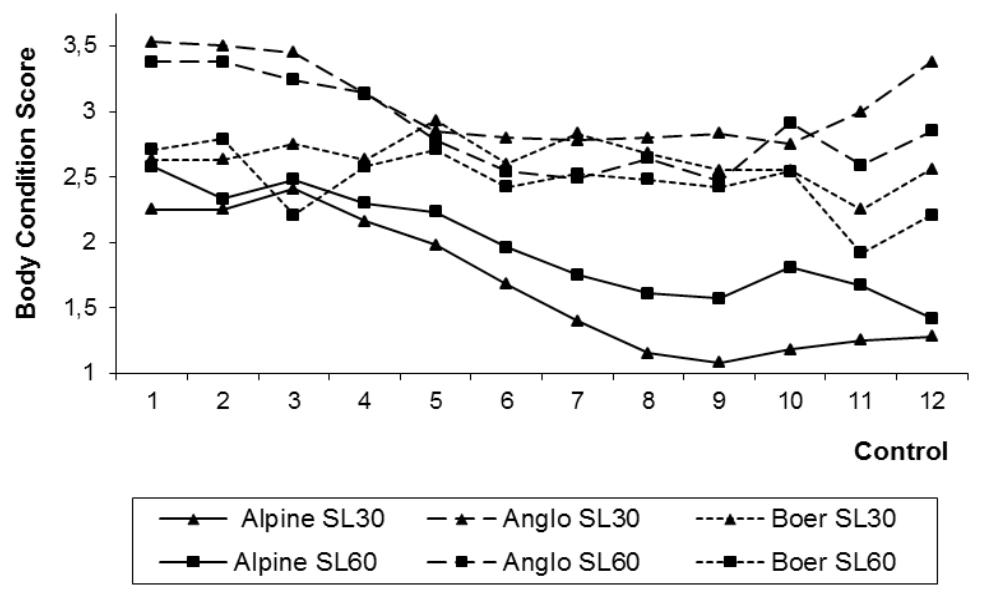

Analysis of variation for the body condition score depending on the breed and concentrate supplementation level (Figure 2) revealed that the body condition score remained constant (Boer) or decreased (Anglo-Nubian and Alpine) during the kidding season. This indicates that the observed increase in body weight (Figure 1) was mainly due to the weight increase of fetuses and fetal annexes.

Subtracting the total birth weight of kids $(7.10,3.30$ and $5.15 \mathrm{~kg}$; Tables 4 and 5) from the difference between live weights recorded during weight control 6 and 1 , revealed live weight variations of $4.10,11.59$ and $-2.62 \mathrm{~kg}$ for Alpine, Anglo-Nubian and crossbred Boer goats, respectively. This might indicate differences among breeds in nutrient partition between fetus and mother. Anglo-Nubian goats prioritized the body condition of mother while compromising kid weight, whereas Alpine goats prioritized kid weight, and crossbred Boers presented an intermediate situation.

Table 4. Goat prolificacy (number of kids per birth), depending on the breed and concentrate supplementation level.

\begin{tabular}{ccccc}
\hline Concentrate & \multicolumn{3}{c}{ Breed } & \multirow{2}{*}{ Total } \\
\cline { 2 - 4 } Supplementation Level $^{1}$ & Alpine & Anglo-Nubian & Boer Crossbred & \\
\hline SL30 & $1,83 \mathrm{Aa}$ & $1,20 \mathrm{Bb}$ & $1,33 \mathrm{Bb}$ & 1,47 \\
SL60 & $1,50 \mathrm{Aa}$ & $1,67 \mathrm{Aa}$ & $1,83 \mathrm{Aa}$ & 1,67 \\
\hline Total & 1,67 & 1,50 & 1,58 & \\
\hline
\end{tabular}

${ }^{1} \mathrm{SL} 30: 300 \mathrm{~g} \mathrm{~kg}^{-1}$ of the daily nutritional requirements, and SL60: $600 \mathrm{~g} \mathrm{~kg}^{-1}$ of the daily nutritional requirements. Averages denoted by different upper case letters (A, B) within the same column, and lower case letters $(\mathrm{a}, \mathrm{b})$ within the same line, are significantly different according to the $\chi^{2}$ test $(p<0.05)$. 
Table 5. Birth weight of kids for different breeds, type of birth and concentrate supplementation level.

\begin{tabular}{|c|c|c|}
\hline \multicolumn{3}{|c|}{ Breed of the Goat } \\
\hline Alpine & Anglo-Nubian & Boer Crossbred \\
\hline $4,25 \mathrm{a}$ & $2,22 \mathrm{c}$ & $3,26 \mathrm{~b}$ \\
\hline \multicolumn{3}{|c|}{ Type of Birth } \\
\hline$\underline{\text { Simple }}$ & Double & Triple \\
\hline $3,73 \mathrm{a}$ & $3,30 \mathrm{~b}$ & $2,70 \mathrm{~b}$ \\
\hline \multicolumn{3}{|c|}{ Concentrate Supplementation Level $^{1}$} \\
\hline$\underline{\text { SL30 }}$ & & $\underline{\text { SL60 }}$ \\
\hline $3,10 \mathrm{~b}$ & & $3,39 \mathrm{a}$ \\
\hline
\end{tabular}

${ }^{1}$ SL30: $300 \mathrm{~g} \mathrm{~kg}^{-1}$ of the daily nutritional requirements, and SL60: $600 \mathrm{~g} \mathrm{~kg}^{-1}$ of the daily nutritional requirements. Averages denoted by different lower case letters $(\mathrm{a}, \mathrm{b})$ within the same line, are significantly different according to the $\chi 2$ test $(\mathrm{p}<$ $0.05)$.

Body condition scores decreased following birth, between evaluations 6 through 10. This decrease was more pronounced for Alpine than for Anglo-Nubian and crossbred Boer goats. This may be associated with the higher milk production observed in Alpine goats, and consequent high mobilization of energy from body reserves, since body reserves are used more efficiently than the energy originating from food (AFRC, 1998).

Prolificacy was affected by breed and concentrate supplementation level (Table 4), and was higher for Alpine than for Anglo-Nubian and crossbred Boer goats at SL30, although not significantly different among breeds at SL60 (Table 4). This may be due to the higher number of primiparous goats in Anglo-Nubian and crossbred Boer breeds supplied with SL30, since the birth order affects prolificacy. The reproductive systems of primiparous females are not completely developed, which might cause abnormalities in female gametes, decreasing herd prolificacy (SARMENTO et al., 2010).

Prolificacy of Anglo-Nubian and crossbred Boer goats was higher with SL60 than with SL30 (Table 4). This is in agreement with the results of Sarmento et al. (2010), who observed that higher nutritional level of females at the time of mating improved ovulation rates, resulting in higher prolificacy.
The average birth weight of kids was affected by breed, type of birth, and concentrate supplementation level (Table 5).

Birth weight was higher for Alpine kids, followed by crossbred Boer and Anglo-Nubian kids. This was probably related to the characteristics of breeds or genetic groups. Dairy goat breeds usually have heavier kids, which may be related to nutrient partition, as discussed above, whereas AngloNubian goats tend to have lighter kids, with average birth weight $3.18 \mathrm{~kg}$ (MEDEIROS et al., 2004b).

Kids from single births were heavier. This is usually related to intrauterine environment, which is directly affected by the nutritional status during pregnancy. It should be noted that the nutrient intake of the goat gets divided among all gestating fetuses. Therefore, higher number of fetuses results in lower quantity of nutrients allocated to each fetus, and consequently poorer body development, resulting in lighter kids. In the present study, kids from single births were $11.5 \%$ and $27.6 \%$ heavier than the kids from double and triple births, respectively (Table 5).

Goats receiving SL60 gave birth to heavier kids than those receiving SL30. This was likely due to higher nutrient intake during the whole pregnancy, and especially during the final third part, resulting in increased kid growth. 
Concentrate supplementation level did not affect the lactation curve characteristics (Table 6). This indicates that both supplementation levels resulted in similar body reserve deposition.
This was also indicated by the body condition scores, which showed similar time to reach peak milk production, peak milk production, and milk production during the first 110 days of lactation, at both supplementation levels.

Table 6. Time to reach peak milk production (TP), peak milk production (PP), and total milk production (MP), for goats of different breeds. Data are represented as averages.

\begin{tabular}{|c|c|c|c|}
\hline \multirow[b]{2}{*}{ Breed } & \multicolumn{2}{|r|}{ Characteristic } & \multirow[b]{2}{*}{$\mathrm{MP}(\mathrm{kg})$} \\
\hline & TP (days) & $\mathrm{PP}(\mathrm{kg})$ & \\
\hline Alpine & $47,63 \mathrm{a}$ & $3,04 \mathrm{a}$ & $265,88 \mathrm{a}$ \\
\hline Anglo-Nubian & $34,61 \mathrm{ab}$ & $2,40 \mathrm{a}$ & $211,95 \mathrm{a}$ \\
\hline Boer Crossbred & $25,58 \mathrm{~b}$ & $1,07 \mathrm{~b}$ & $98,19 \mathrm{~b}$ \\
\hline Average & 35,94 & 2,17 & 192,00 \\
\hline $\mathrm{CV}^{1}$ & 47,93 & 40,84 & 43,23 \\
\hline
\end{tabular}

${ }^{1}$ Coefficient of variation. Averages denoted by different letters $(a, b)$ within the same column, are significantly different according to the $\chi 2$ test $(\mathrm{p}<0.05)$.

The time to reach peak milk production was higher for Alpine than for crossbred Boer goats, and peak milk production and milk production at 110 days of lactation were higher for Alpine and Anglo-Nubian than for crossbred Boer goats (Table 6). The higher milk production by Alpine goats can be attributed to their higher milking potential and high capacity of mobilizing energy from body reserves in order to meet the demands of higher milk production. This is also indicated by their higher weight loss following kidding and in the beginning of lactation (weighings 6 through 7) (Figure 1).

During the first 110 days lactation, the adopted production system resulted in an average daily milk production of $2.4 \mathrm{~kg}$ and $1.9 \mathrm{~kg}$ for Alpine and AngloNubian goats, respectively. These milk production values are considered adequate, indicating that these two breeds may be suited for this type of system. Milk production is influenced by a combination of factors, such as the use of breeds selected for milk production, adequate nutrition, and management practices (GREYLING et al., 2004).
A significant interaction between breed and concentrate supplementation level was observed for milk production on the day of milk control (Figure 3).

Figure 3. Milk production in different milk controls for goats of different breeds and with different concentrate supplementation levels.

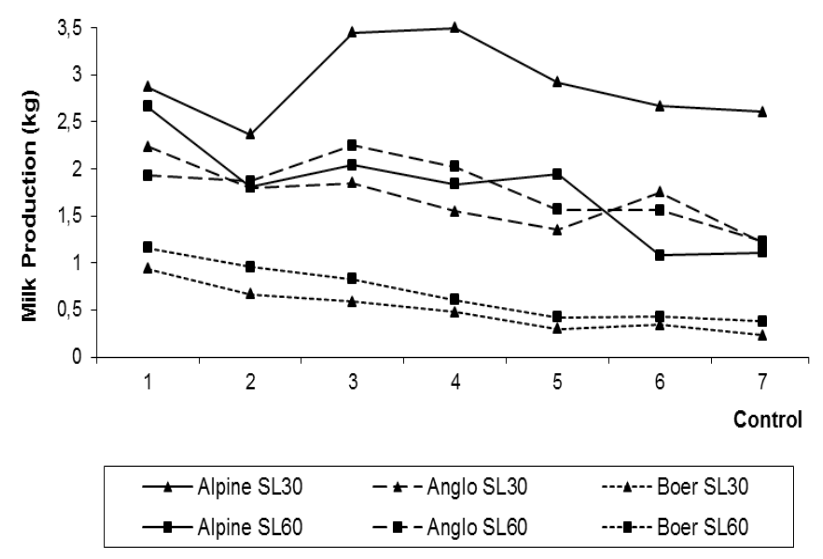


Alpine goats presented higher milk production than crossbred Boer goats, for all milk controls, but not significantly different from Anglo-Nubian goats, with SL60. This was probably due to the capacity of Alpine goats to increase body reserves, which was indicated by their higher body condition score. Body reserves can be used moderately during lactation without compromising the goat's body condition. Silva et al. (2009) also observed higher milk production for Alpine than for crossbred goats. With SL30, Alpine goats recorded higher milk production, supported by mobilization of body reserves, than crossbred Boer for all milk controls, and than Anglo-Nubian goats for all milk controls except 1,6 , and 7 .

A significant effect of the concentrate supplementation level on milk production was only observed for Alpine goats. Beginning with the third milk control, milk production was higher for Alpine goats with SL30 than with SL60. This may be due to the fact that goats receiving SL30 had higher production potential, or that a large number of the goats receiving SL30 were of higher birth order. Physiologically, primipara goats present lower milk production than multipara goats, because their mammary system is still not fully developed (RODRIGUES et al., 2006b).
No differences in milk production between the two concentrate supplementation levels were observed for the remaining breeds. This indicates that the use of lower concentrate supplementation (300 $\mathrm{g} \mathrm{kg}^{-1}$ of the daily nutrient requirements) before kidding, together with the quality of forage and animal selectivity (VAN SOEST, 1987), which enabled the selection and ingestion of the most nutritious plant parts, was sufficient to meet the nutrient requirements.

This selectivity is characteristic of goats, and resulted in the observed differences in bromatological composition of the forage available to the animals before and after grazing, i.e., after selection (Table 3). After grazing, the forage presented lower protein and NDT concentrations, and higher NDF concentrations. This is in accordance with the results of Van Soest (1987), who studied grazing behavior in goats, and observed that following selection, the animals ingested food with higher concentration of cell contents and lower concentration of cell wall.

Total milk solid concentrations were highest for crossbred Boer goats, followed by AngloNubian and Alpine goats (Table 7). This may have been due to lower milk production by crossbred Boer goats, resulting in concentration of the milk components.

Table 7. Milk total solids and defatted dry extract concentrations, for goats of different breeds.

\begin{tabular}{ccc}
\hline Breed & Concentration of Total Solids $\left(\mathrm{g} \mathrm{kg}^{-1}\right)$ & Concentration of Defatted Dry Extract $\left(\mathrm{g} \mathrm{kg}^{-1}\right)$ \\
\hline Alpine & $114,4 \mathrm{c}$ & $81,6 \mathrm{c}$ \\
Anglo-Nubian & $131,2 \mathrm{~b}$ & $88,9 \mathrm{~b}$ \\
Boer Crossbred & $144,6 \mathrm{a}$ & $94,2 \mathrm{a}$ \\
\hline Average & 129,4 & 88,0 \\
\hline $\mathrm{CV}^{1}$ & 11,14 & 8,55 \\
\hline
\end{tabular}

${ }^{1}$ Coefficient of variation. Averages denoted by different letters $(\mathrm{a}, \mathrm{b}, \mathrm{c})$ within the same column, are significantly different according to the $\chi 2$ test $(\mathrm{p}<0.05)$. 
Defatted dry extract concentrations were affected by the breed; they were lower for Alpine than for crossbred Boer goats due to lower milk protein and lactose concentrations (Table 7).
Total milk solid concentrations decreased with increasing stages of lactation (Table 8). This may be related to the variation in milk fat and protein concentrations, which was higher for the first milk controls, resulting in higher concentrations of total solids.

Table 8. Milk total solids and urea nitrogen concentrations for different milk controls.

\begin{tabular}{ccc}
\hline Milk Control & Proportion of Total Solids $\left(\mathrm{g} \mathrm{kg}^{-1}\right)$ & Proportion of Nitrogen Urea $\left(\mathrm{mg} \mathrm{dL}^{-1}\right)$ \\
\hline 1 & $135,5 \mathrm{a}$ & $32,26 \mathrm{c}$ \\
2 & $134,1 \mathrm{a}$ & $33,25 \mathrm{c}$ \\
3 & $126,9 \mathrm{ab}$ & $36,31 \mathrm{abc}$ \\
4 & $127,8 \mathrm{ab}$ & $38,42 \mathrm{a}$ \\
5 & $129,0 \mathrm{ab}$ & $37,92 \mathrm{ab}$ \\
6 & $121,5 \mathrm{~b}$ & $33,56 \mathrm{bc}$ \\
7 & $121,0 \mathrm{~b}$ & $35,19 \mathrm{abc}$ \\
\hline Average & 129,4 & 35,33 \\
\hline CV & 11,14 & 16,79 \\
\hline
\end{tabular}

${ }^{1}$ Coefficient of variation. Averages denoted by different letters $(a, b, c)$ within the same column, are significantly different according to the $\chi 2$ test $(\mathrm{p}<0.05)$.

Urea nitrogen concentration (UN) was affected by the milk control (Table 8 ). However, it was not positively correlated with milk production, as suggested by Meyer et al. (2006). The observed average of $35.33 \mathrm{mg} \mathrm{dL}^{-1}$ was higher than previously reported (FERREIRA et al., 2012), indicating excess protein or an energy-protein imbalance in the diet. The excess protein may be related to the high forage protein concentration, as several fertilizations were performed during the experiment, resulting in forage with good bromatological composition (Table 3).

UN concentrations are considered a good indicator of the energy:protein ratio of feed, such that high UN concentrations indicate lower nitrogen use efficiency in milk production for diets with high concentrate supplementation levels (BONANNO et al., 2008).

A significant interaction between breed and concentrate supplementation level, and a significant effect of milk control, were observed for the milk fat concentration (Figure 4). Average fat concentration was $41.4 \mathrm{~g} \mathrm{~kg}^{-1}$. Crossbred Boer goats presented the highest milk fat concentrations, and Alpine goats the lowest. This may be due to the lower milk production of crossbred Boer goats, resulting in concentration of fat, while the opposite being true for Alpine goats. 
Figure 4. Milk fat concentration for goats of different breeds and with different concentrate supplementation levels.

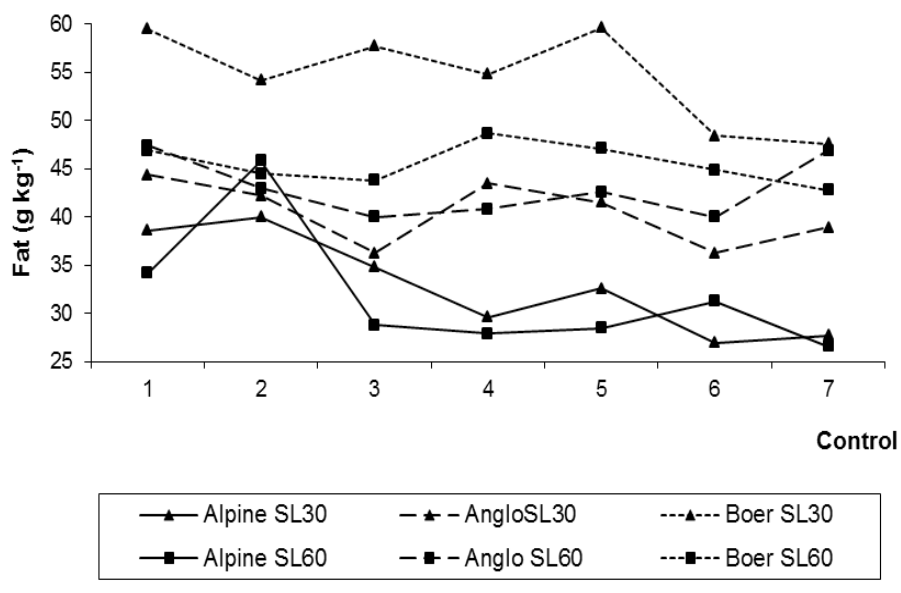

Milk fat concentrations of Anglo-Nubian goats were closer to those of Alpine goats for the treatment with SL30, for all milk controls, but closer to those of crossbred Boer goats for the SL60 treatments. A significant effect of the concentrate supplementation level was observed only for crossbred Boer goats, which presented higher milk fat concentrations with SL30 than with SL60. This may have been due to lower milk production with SL30, which despite statistically insignificant difference, could have contributed to the concentration of fat.

A significant interaction between breed and concentrate supplementation level, and a significant effect of milk control, were observed for milk protein concentrations (Figure 5). Average protein concentration was $35.5 \mathrm{~g} \mathrm{~kg}^{-1}$. No differences were observed between different concentrate supplementation levels for the three breeds, which may be due to the good quality of the forage available to the goats. For most milk controls, with SL30, Alpine and Anglo-Nubian goats presented similar average milk protein concentrations, and lower than crossbred Boer goats. With SL60 the milk protein concentrations of Anglo-Nubian goats were closer to those of crossbred Boers, and higher than Alpine goats. This may be due to the higher milk production by Alpine goats, and consequent dilution of the milk components.

Figure 5. Milk protein concentration for goats of different breeds and with different concentrate supplementation levels.

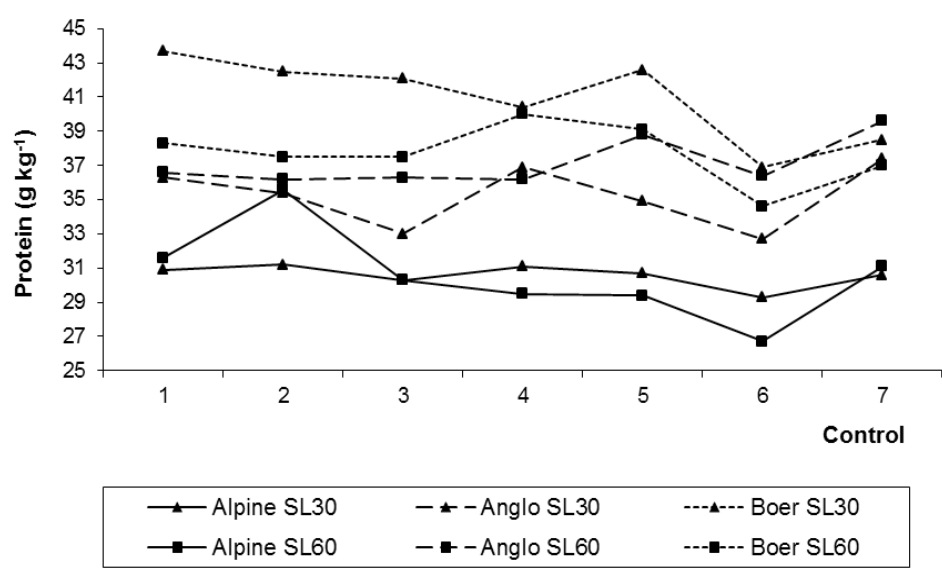


Milk lactose concentrations were influenced by breed, concentrate supplementation level, and milk control (Figure 6). Average lactose concentration was $44.5 \mathrm{~g} \mathrm{~kg}^{-1}$. There was little variation in lactose concentrations during lactation. Lactose is the main component responsible for drawing water into the milk, being directly related to the regulation of osmotic pressure. Therefore, it is usually maintained at constant levels, and is considered the most stable milk component (QUEIROGA et al., 2007).

Figure 6. Milk lactose concentration for goats of different breeds and with different concentrate supplementation levels.

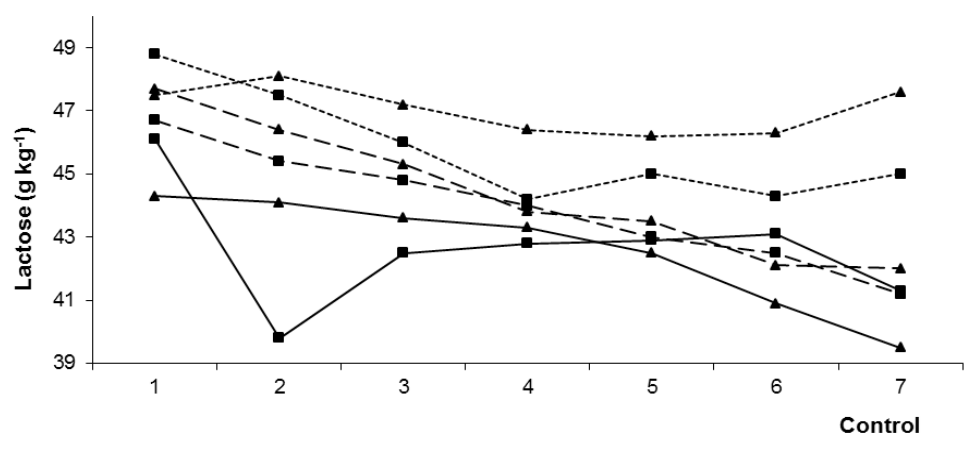

\begin{tabular}{lll|}
$\longrightarrow \rightarrow$ Alpine SL30 & $-\star-$ Anglo SL30 & ----- Boer SL30 \\
$\rightarrow-$ Alpine SL60 & - - -Anglo SL60 & ----- Boer SL60 \\
\hline
\end{tabular}

Milk somatic cell counts (SCC) were affected by breed, concentrate supplementation level, and milk control (Figure 7). With SL60, a significant effect of breed was observed for milk controls 3 through 6, with Alpine and crossbred Boer goats presenting higher SCC than Anglo-Nubian goats.
This may be attributed to the higher birth order of the goats used from these two breeds. Multipara goats present higher SCC, due to decreased udder health and higher desquamation of epithelial cells with increasing number of lactations. This is in accordance with Rodrigues et al. (2006b).

Figure 7. Somatic cell counts (SCC) in milk for goats of different breeds and with different concentrate supplementation levels.

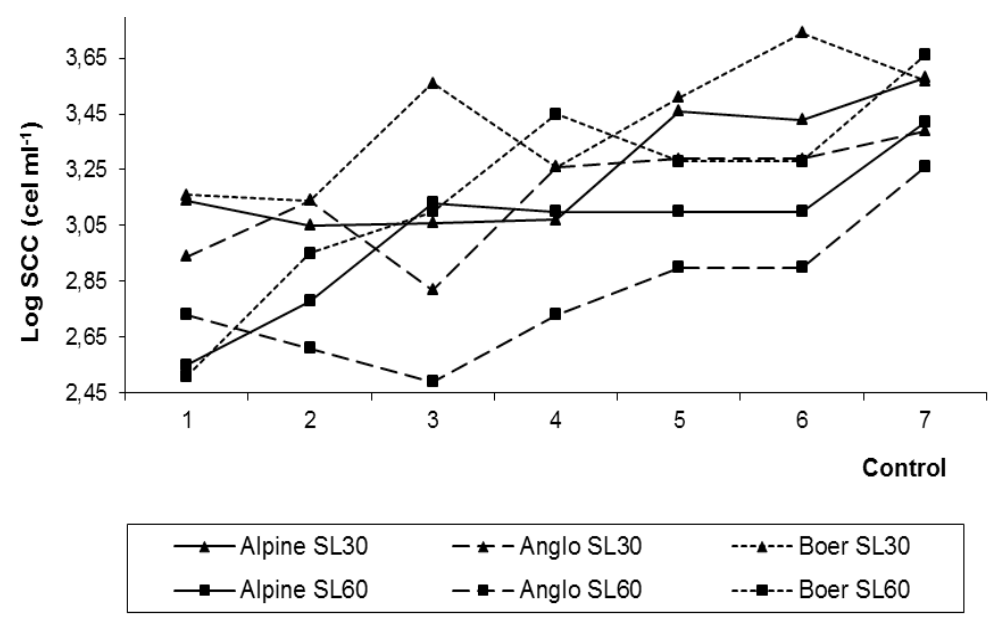




\section{Conclusions}

The concentrate supplementation levels tested on the rotational grazing system were sufficient to promote adequate fetus development, but resulted in limited deposition of body reserves.

Differences in nutrient partition between mother and fetus, and in deposition of body reserves, were observed across breeds. Anglo-Nubian goats prioritized body reserves, producing kids with lower birth weight, Alpine goats prioritized fetuses, and crossbred Boers presented an intermediate situation.

SL60 supplementation had a positive effect on birth weight and prolificacy of Anglo-Nubian and crossbred Boer goats, which prioritize deposition of body reserves.

Following birth, the goats received diet supplementation according to their milk production. Animals presenting higher milk production at the beginning of lactation received higher supplementation, and consequently presented higher milk production during the whole lactation period. It also resulted in changes in some milk components, such as lower fat and protein concentrations.

Alpine and Anglo-Nubian goats presented similar milk production, which may be indicative of pasture-based production systems. Anglo-Nubian goats presented higher total solids concentrations, especially fat and protein concentrations, and better body condition, which might be important in the case of forage scarcity.

\section{Acknowledgments}

The authors wish to thank the Foundation for Research Support of the State of São Paulo for the concession of the scholarship (Process: 2010/04566-0).

\section{References}

AGRICULTURAL AND FOOD RESEARCH COUNCIL - AFRC. The nutrition of goats. New York: CAB International, 1998. v. 67, n. 11, 118 p.

ASSOCIATION OF OFFICIAL ANALYTICAL CHEMISTRY - AOAC. Official methods of analysis of the Association of Official Analytical Chemists. $18^{\text {th }}$ ed. Gaithersburg: AOAC International, 2005. 3000 p.

BONANNO, A.; FEDELE, V.; DI GRIGOLI, A. Grazing management of dairy goats on Mediterranean herbaceous pasture. In: CANNAS, A.; PULINA, G. (Ed.). Dairy goats feeding and nutrition. Wallingford: $\mathrm{CAB}$ International, 2008. p. 189-220.

EKNAES, M.; KOLSTAD, K.; VOLDEN, H.; HOVE, $\mathrm{K}$. Changes in body reserves and milk quality throughout lactation in dairy goats. Small Ruminant Research, Amsterdam, v. 63, n. 1, p. 1-11, 2006.

FERREIRA, F. A.; SANTOS, E. J.; PEREIRA, M. L. A.; BARRETO, F.; BORGES, L.; CHAGAS, D. M. T.; ALMEIDA, P. J. P.; OLIVEIRA, L. N. Excreção de ureia em cabras lactantes alimentadas com dietas contendo níveis de proteína bruta em concentrados peletizados. Revista Científica de Produção Animal, Teresina, v. 14, n. 2, p. 192-195, 2012.

GREYLING, J. P. C.; MMBENGWA, V. M.; SCHWALBACH, L. M. J.; MULLER, T. Comparative milk production potential of Indigenous and Boer goats under two feeding systems in South África. Small Ruminant Research, Amsterdam, v. 55, n. 1, p. 97-105, 2004.

MEDEIROS, G. R.; PIMENTA FILHO, E. C.; SOUSA, W. H.; BRITO, E. A. Peso à cobrição e ganho de peso durante a gestação de cabras nativas, exóticas e mestiças no semi-árido. Revista Brasileira de Zootecnia, Viçosa, MG, v. 33, n. 6, p. 1711-1720, 2004a. Suplemento.

MEDEIROS, L. F. D.; VIEIRA, D. H.; LUNA, M. C. M.; CABRAL NETO, O. Avaliação de alguns aspectos de desempenho de caprinos da raça Anglo-Nubiana, no estado do Rio de Janeiro. Revista Universidade Rural, Série Ciências da Vida, Seropédica, v. 24, n. 2, p. 103118, 2004b.

MEDEIROS, L. F. D.; VIEIRA, D. H.; RODRIGUES, V. C.; BARBOSA, C. G.; SCHERER, P. O. Características de reprodução, peso ao nascer e mortalidade de caprinos Anglo-nubianos, no município do Rio de Janeiro. I Fatores que afetam o período de gestação, fertilidade e prolificidade. Revista Brasileira de Ciência Veterinária, Niterói, v. 13, n. 1, p. 37-43, 2006. 
MEYER, P. M.; MACHADO, P. F.; COLDEBELLA, A.; CASSOLI, L. D.; COELHO, K. O.; RODRIGUES, P. H. M. Fatores não-nutricionais e concentração de nitrogênio ureico no leite de vacas da raça Holandesa. Revista Brasileira de Zootecnia, Viçosa, MG, v. 35, n. 3, p. 11141121, 2006. Suplemento.

NATIONAL REASEARCH COUNCIL - NRC. Nutrient requirements of small ruminants. Washington, D.C.: The National Academy Press, 2006. 362 p.

QUEIROGA, R. C. R. E.; COSTA, R. G.; BISCONTINI, T. M. B.; MEDEIROS, A. N.; MADRUGA, M. S.; SCHULER, R. P. Influência do manejo do rebanho, das condições higiênicas da ordenha e da fase de lactação na composição química do leite de cabras Saanen. Revista Brasileira de Zootecnia, Viçosa, MG, v. 36, n. 2, p. 430437, 2007.

RODRIGUES, C. A. F.; RODRIGUES, M. T.; BRANCO, R. H.; QUEIROZ, A. C.; ARAÚJO, C. V. Influência da condição corporal e da concentração de energia nas dietas no periparto sobre o desempenho de cabras em lactação. Revista Brasileira de Zootecnia, Viçosa, MG, v. 35, n. 4, p. $1560-1567,2006 a$.

RODRIGUES, C. A. F.; RODRIGUES, M. T.; BRANCO, R. H.; SILVA, M. M. C. Consumo, digestibilidade e produção de leite de cabras leiteiras alimentadas com dietas contendo diferentes níveis de proteína bruta e energia líquida. Revista Brasileira de Zootecnia, Viçosa, MG, v. 36, n. 5, p. 1658-1665, 2007.

RODRIGUES, L.; SPINA, J. R.; TEIXEIRA, I. A. M. A.; DIAS, A. C.; SANCHES, A.; RESENDE, K. T. Produção, composição do leite e exigências nutricionais de cabras Saanen em diferentes ordens de lactação. Acta Scientiarum Animal Science, Maringá, v. 28, n. 4, p. 447452, 2006b.
ROLIM, G. S.; CAMARGO, M. B. P.; LANIA, D. G.; MORAES, J. F. L. Classificação climática de Köppen e de Thornthwaite e sua aplicabilidade na determinação de zonas agroclimáticas para o estado de São Paulo. Revista Bragantia, Campinas, v. 66, n. 4, p. 711-720, 2007.

SALMAN, A. K. D.; SOARES, J. P. G.; CANESIN, R. C. Métodos de amostragem para avaliação quantitativa de pastagens. Porto Velho: EMBRAPA, 2006. 6 p. (Circular técnica, 84).

SARMENTO, J. L. R.; PIMENTA FILHO, E. C.; ABREU, U. G. P.; RIBEIRO, M. N.; SOUSA, J. E. R. Prolificidade de caprinos mestiços leiteiros no semiárido nordestino. Revista Brasileira de Zootecnia, Viçosa, MG, v. 39, n. 7, p. 1471-1476, 2010.

SILVA, V. N.; RANGEL, A. H. N.; BRAGA, A. P.; MAIA, M. S.; MEDEIROS, H. R. Influência da raça, ordem e ano de parto sobre a produção de leite caprino. Acta Veterinária Brasílica, Mossoró, v. 3, n. 4, p. 146150, 2009.

UNIVERSIDADE FEDERAL DE VIÇOSA - UFV. Sistema de análises estatísticas e genéticas - SAEG. Versão 9.0. Viçosa, MG: FUNARBE, 2000.

VAN SOEST, P. J. Interaction of feeding behavior and forage composition. In: INTERNATIONAL CONFERENCE ON GOATS, 4., 1987, Brasília. Anais... Brasília: EMBRAPA, 1987. p. 971-987.

VAN SOEST, P. J.; ROBERTSON, J. B.; LEWIS, B. A. Symposium: carbohydrate methodology, metabolism, and nutritional implications in dairy cattle. Journal of Dairy Science, Madison, v. 74, n. 10, p. 3583-3597, 1991.

WOOD, P. D. P. Breed variation in the shape of the lactation curve of cattle and their implications for efficiency. Journal of Animal Science, Champaign, v. 31, n. 2, p. 133-141, 1980. 